Fifth Session of the FAO Technical Working Party on Coconut Production, Protection \& Processing Manila, Philippines, 3-8 December 1979.

\title{
THE PROBABLE ORIGIN OF LETHAL YELLOWING AND ITS CO-IDENTITY WITH OTHER LETHAL DISEASE OF COCONUT
}

\author{
L. Chiarappa ${ }^{1}$ \\ Plant Production \& Protection Division FAO, Rome, ltaly
}

\begin{abstract}
Summary
The working hypothesis is put forward that Lethal Yellowing (LY) disease of coconut originated in Southeast Asia, where the disease is now endemic due to the prevalence of locally resistant to moderately resistant varieties.

The suggestion is made that LY is co-identical with other lethal diseases of coconut characterized by different symptorn expression. These differences are due to certain morphological and physiological characteristics inherent in coconut 'groups' of different origin.

A hypothesis is also advanced on the existence of different strains of LY, which would explain the differences in susceptibility of certain varieties when grown in different locations. The need for coordinated research to confirm or reject these hypotheses is discussed.
\end{abstract}

\section{Endemic balance andgene centresfor resistance}

A disease is endemic when it is pecullar to a locality where it is constantly present to a greater or lesser extent. This is the opposite of epidernic disease which is instead sporadic and it occurs within a limited time. Endemicity implies both the coexistence of the pathogen and of the host and the resulting balanced disease system (29). Coexistence means that the pathogen and the host must be able to live together. This, for obligate parasites such as viruses and plant pathogenic prokaryotic organisms, also means that the amount of disease must constantly vary but not reach zero level with consequent local extinction of the parasite. Due to variations in local conditions, the disease may flare up suddenly and become more destructive, when it subsides again to a low, almost undetectable level in a sort of cyclic fashion. When an epidemic disease occurs over a large area, this is described as "protean": bulging here and shrinking there like an amoeba (29).

A balanced disease system means that resistance of the host under normal. enviromnental conditions is sufficient to maintain a low level of harmful infections. Under such conclitions, there would be no more than one daughter infected plant per parent infected plant per population. An endermic situation is usually reached after a long period of co-existence of the pathogen and the host In a given habitat where different levels of fitness of the pathogen and the host condition the efficient evolutionary change of both (33).

A balanced systern is always site-specific. Thus trains of the pathogen that appear to have a low level of virulence under a localized endernic situation may, instead, be highly virulent on the same host if this is removed frorn the endemic centre and grown under different ecological conditions. Likewise, if a given host plant is moved to a parasite free area, the balanced system. is

\footnotetext{
${ }^{1}$ The original proceedings had limited circulation and this document was not published separately. It is reproduced here with the permission of the original author, Dr. Luigi Chiarappa, 4221 Montgomery Avenue, Davis CA 95616, USA.
} 
lost and the host may consequently lose its original resistance. A classical example is that of Puccini polysora, the cause of a relatively unimportant rust disease of maize in the Western Hemisphere. When this fungus reached Africa in the late 1940s after having been out of contact with maize on this continent for nearly four centuries, it caused an extensive epidemic. However, within a short number of generations and recurrent selection the resistance of African corn was established without recourse to the introduction of foreign resistance genes.

Due to the efficient co-evolution of host and pathogen, under endermic conclitions there seems to be some positive correspondence between. centres of origin or diversity of a given crop and frequencies of genes for resistance to a given obligate parasite (15). Also the reverse has been proposed by which it would be possible to trace the gene centre of a cultivated crop on the basis of the existence in a given area of a host-specific pest or pathogen (15).

In this paper the working hypothesis is put forward that Lethal Yellowing originated in Southeast Asia, where it is now present and endermic, that Lethal Yellowing is co-identical with other lethal diseases occurring in this and other areas and that the resistance still found in this part of the world provides evidence for the common origin of certain groups of cultivated Cocos nucifera (10). This will be achieved by an analysis of the following facts.

\section{Origin-related coconut morphology, physiology and susceptibility to Lethal Yellowing}

Whitehead $(30,31,32)$ observed a direct relationship between fruit composition and rate of gerniination of coconut seed. He also noted that fruit and nut shape, as well as interval between flowering and nut maturity, characterized difference between distinct 'groups' of coconuts derived from various areas. These groups also appeared to differ in their susceptibility to Lethal Yellowing and, as discussed later, in their symptorn expression. Whitehead (32) suggested that relationships of this nature could be used not only mi taxonornic studies on Cocos nucifera, but also to provide useful information on the origin of this species.

According to analyses made by Whitehead on fi-uit charactenistics and seed gerniination rates of coconut germplasm introduced to Jamaica from Peru and the Indian/Malaysian region under FAO assistance ${ }^{2}$, two broad groups could be differentiated (32). They resembled either the "Panama Tall" (which Whitehead called "San Blas") or the "Jamaica Tall". This is summarized in Table 1.

It should be noted that the tall coconuts from Malaysia, Sarawak and Thailand and the Malayan Dwarf (the latter originated probably in Indonesia) all come from Southeast Asia. Also the "Panama Tall", whose distribution is on the Pacific coast of Central and South America including Peru, is believed to have originated in Southeast Asia and, more precisely, in the Philippines. From this country it was brought to Mexico by the Spaniards in the 16th century (19). Instead, the similarity between the "Jamaica Tall" with coconuts growing on the Atlantic coast of America, West Africa, East Africa, Ceylon and India supports the origin of this "group" in the Indian sub-continent with a centre of dissemination to the western hemisphere in the Cape Verde Islands (2).

A comprehensive discussion of the evollation of the two main types of coconut and their geographical distribution and predominance, based on fruit component analysis, response to Lethal Yellowing and other factors, is given by Harries (10). The "Niu Kafa" group ${ }^{3}$, which includes the "Jamaica Tall" and the true "San Blas" varieties, evolved naturally, whereas the "Niu Vai" group, which includes the "Panama Tall", resulted from selection under cidtivation.

\footnotetext{
${ }^{2}$ Following other introductions to Jamaica from the Pacific region with ODA assistance (31)

3 The terms "Wild type" and "domestic type" are preferred to "Niu kafa group" and "Niu vai group" arid intermediate, "introgressed types", also occurs. (Harries, H.C. (1995) Coconut: In J. Smartt \& N.W. Simmonds (eds) Crop Plant Evolution (2nd edition) Longman pp. 389-394).
} 
It is clear that differences in susceptibility to LY cannot be purely accidental. Instead, it would seem likely that coconuts of India/Ceylon origin did develop in areas separated from where Lethal Yellowing is endernic.

TABLE I. Seed germination rates, flowering and fruit characteristics as they relate to LY Susceptibility and taxonomic differentiation in Cocos nuciferea $\mathrm{L}$.

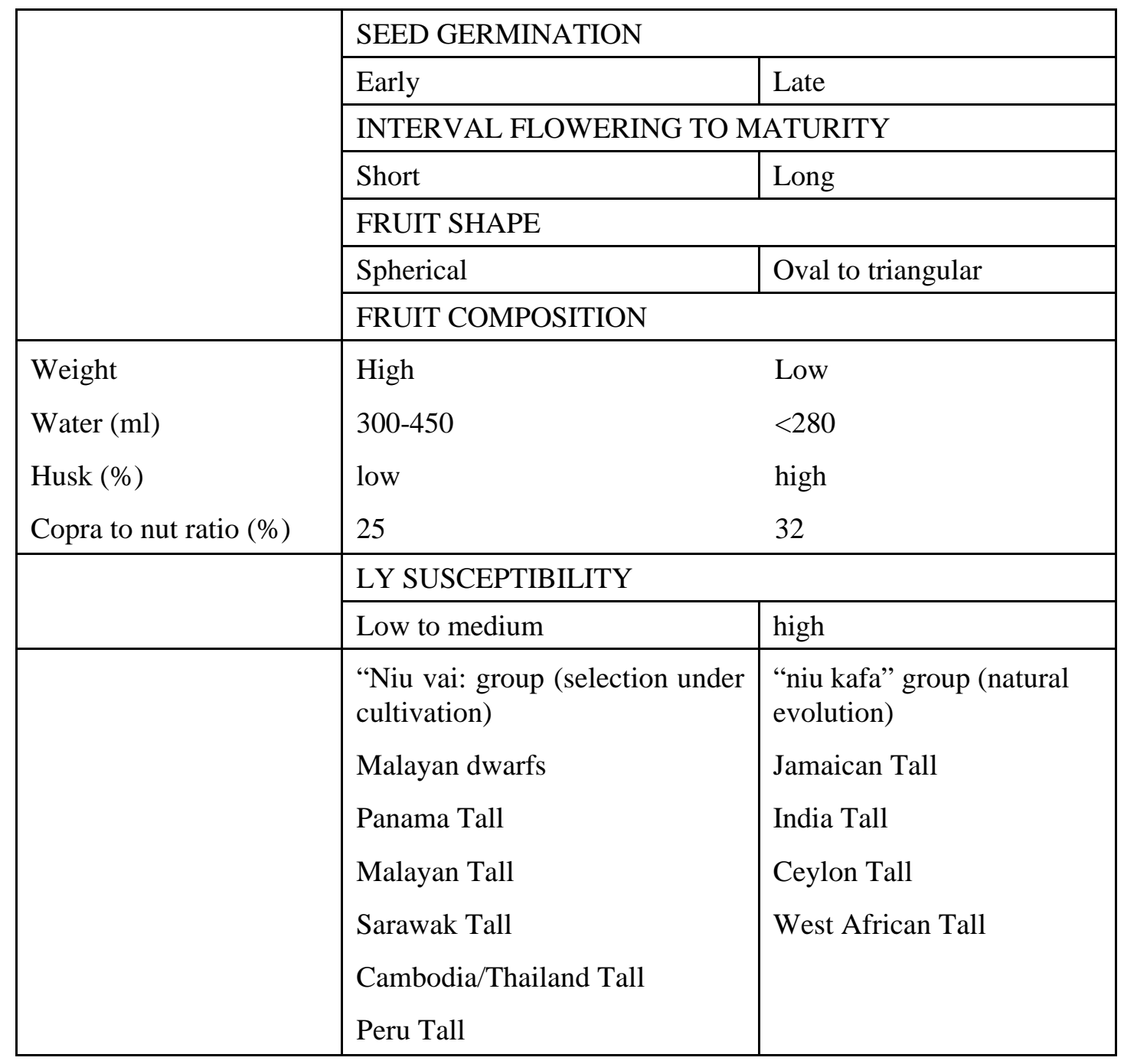

\section{Ranking of disease resistance}

Harries (9) as early as 1973 recogruzed three main levels of resistance to Lethal Yellowing according to which he could group the introduced or indigenous coconuts growing in Jamaica. The highly resistant category included only the "Malayan Dwarf" (with 3\% losses to the disease). The intermediate resistant categories included varieties from the Pacific Islands). In the highly susceptible group, ranging from 62 to $95 \%$ losses, Harries placed the "Ceylon Tall", the "Indian Tall" and the "Jamaica Tall" (in addition to other palms (sic) from the Pacific).

In 1976, the Coconut Industry Board of Jamaica, (2) tabulated the incidence of the LY disease on local and introduced varieties in six different locations. This information was updated mi 1979 (21). These data, although valuable in giving an overall indication of the level of resistance, are difficult to interpret analytically because of the variation in number of individuals, differences in age and inoculum potential. at each test location. 
We have therefore extracted information only from two locations (Caenwood and Orange river) where palms were planted in plots replicated four times and where two different "levels" of inoculum existed. We have also limited our analysis to the germplasm introduced under-FAO assistance in 1967. This information is shown in Table II.

Table II. Losses to LY of coconut germplasm from India/Malaysian regions And Peru at two locations in Jamaica ${ }^{6}$

\begin{tabular}{|l|c|c|c|c|}
\hline \multirow{2}{*}{\multicolumn{1}{|c|}{ Germplasm Source }} & \multicolumn{4}{|c|}{ Location } \\
\cline { 2 - 5 } & \multicolumn{2}{|c|}{ Caenwood } & \multicolumn{2}{c|}{ Orange River } \\
\cline { 2 - 5 } & Planted (No) & Dead (\%) & Planted (No) & Dead (\%) \\
\hline Malaya I & 48 & 33.3 & 48 & 22.9 \\
Malaya II & 48 & 41.7 & 48 & 29.2 \\
Thailand & 48 & 47.9 & 48 & 18.7 \\
Sarawak & 48 & 39.6 & - & - \\
Cambodia & - & - & 48 & 29.2 \\
Peru & 48 & 37.5 & - & - \\
Average & 48 & 40.0 & 48 & 25.0 \\
Jamaica T.x Malaya T (BSIP) & - & - & 48 & 91.7 \\
Jamaica Tall & 48 & 83.3 & 48 & 91.7 \\
Ceylon & 48 & 64.6 & 48 & 91.7 \\
India & 24 & 95.8 & - & - \\
Average & 40 & 81.2 & 48 & 79.2 \\
Malayan dwarf (local) & 96 & 12.0 & 29 & 0.0 \\
\hline
\end{tabular}

${ }^{6}$ Source: Romney, D.H. (21)

Although different levels of disease were present in the two locations, the similarity and uniformity in resistance are quite striking in the material from the Malaysian region. (Niu Vai group) vis-a-vis that from the Indian region (Niu Kafa group)

A point to consider is also that of the lower incidence of the disease at Orange River, where lethal yellowing was not present at the time of planting. It is important to note that under such conditions the disease level of the tall Malaysian material. is closer to one third that of the Indian material, instead of nearly half, as at the other location. This is an important point to bear in mind when considering vulnerability of Malaysian material under conditions of low inoculum level such as those that could exist mi a pure stand of semi-resistant tall coconuts in Malaysia or Indonesia. Harries observed that resistance of the "Panama Tall" was greater in original. plantings than in subsequent progenies (8). He also suggested that if a MLO (mycoplasma-like organisms) disease ${ }^{4}$, such as Lethal Yellowing did exist in countries where coconut varieties were predominantly not highly susceptible, this disease would be unnoticed (11). This situation appears to exist in Southeast Asia where, until recently, most of the grown varietles belong to the "Niu Vai" group (10) having mitermediate to high resistance to Lethal Yellowing when tested under Jamaican conditions (9).

\footnotetext{
${ }^{4}$ The terms "MLO" and "mycoplasma-like organism", used for diseases such as lethal yellowing, have now been replaced by the term "phytoplasma" (Eden Green, S.J. (1997) History, world distribution and present status of lethal yellowing-like diseases of pahns. In: S.J. Eden-Green \& F. Ofori (eds.) Proc. Int. Wkshp. LY-Like Diseases of Coconut, Elmina, Ghana. Pp. 9-25).
} 
Also of interest in Table II is the behaviour of the cross "Jamaica Tall x Malaya Tall (BSIP)" which shows an intermediate level of resistance between the two progenitors from the "Niu Vai" and "Niu Kafa" groups.

\section{Symptomatology}

Lethal Yellowing is so called because of the bright or butter-yellow discoularation of the leaves. This symptom is - typically seen on susceptible "Jamaica Tall" or "West African Tall". However, Lethal Yellowing disease in "Panama Tall" variety does not produce any yellowing (32). Instead symptoms are characterised by a progressive discouloration and brown-bronzing leaflets and by the gradual wilting and drying of the lower whorls, which remain vertically suspended from the apex of the trunk. The midribs of some of the younger fronds break about half way along. These symptoms, which are also seen in "Malayan Dwarf" (yellow and green) (5), are similar to those attributed to Malaysian wilt (32). Marmorosch already stated that " it is possible that Malaysian wilt is related to Lethal Yellowing with modifications caused by the reaction of highly resistant Malayan coconut varieties" (17). This statement is now further supported by evidence obtained in Jamaica on symptom expression of diseased "Malayan Tall", "Panama Tall" and other exotic materials including the same "Malayan Dwarf" when these become diseased (5,32).

\section{Susceptibility of exotics}

\section{Indonesia and Malaysia}

Considerable quantities of foreign seed matenial have been introduced mi recent years into Indonesia, Malaysia and other Southeast Asian countries. Most of these introduction consisted of hybrid "Malayan Dwarf x West African Tall". In Sumatra and Java in Indonesia, a significant number of seedlings and of young palms of this matenal died within the period varying from 13 to 32 months, while all local material planted at the same time and at the same site remained healthy or nearly healthy. This is indicatedmi Table III.

Table III. Death of imported and native coconut pahns at two locations in Indonesia ${ }^{7}$

\begin{tabular}{|c|l|r|r|}
\hline \multicolumn{1}{|c|}{ Location } & \multicolumn{1}{|c|}{ Variety } & \multicolumn{1}{c|}{$\begin{array}{c}\text { Palms } \\
\text { Planted No. }\end{array}$} & $\begin{array}{c}\text { Palms Dead } \\
\%\end{array}$ \\
\hline Medan (a) & MD x WAT & 7,079 & 11.24 \\
& Local Tall & 625 & 0.00 \\
& Loca Dwarf (Nias) & 1,250 & 0.32 \\
& Malayan Dwarf (Yellow) & 1,250 & 0.08 \\
\hline Bandung (b) & MD x WAT & 3.595 & 8.76 \\
& Nias Dwarf x Bali Tall & 200 & 1.50 \\
& Bali Tall (open Pollinated) & 200 & 4.00 \\
& Malayan Dwarf (Yellow) & 158 & 0.00 \\
\hline (a) Seedlings planted in soil. Readings taken after 32 months. \\
(b) Nuts planted in polybags. Readings taken after 13 months. \\
\hline
\end{tabular}

${ }^{7}$ Source: Liyanage, D.V. (Personal communication) (16)

External symptoms of dying palms were somewhat similar to those of young seedlings affected by "dry bud rot" in Ivory Coast (20) and of non-bearing palms affected by LY in Jamaica. A similar wilt disease was recently observed in Peninsular Malaysia on hybrid "Malayan Dwarf x West African Tall" produced locally (16). Hybnid losses in Lower Perak have been reported to be in the 
order of $3.5 \%$ after three years in one location (12), and $10 \%$ in the nursery and $15 \%$ in the field during the first two year in another location (24). Presence of MLO's in tissues of only diseased palms from Sumatra and Peninsular Malaysia has recently been reported (27). The susceptibility of exotics when compared with resistance of native coconuts and the association with MLO's in diseased coconuts provide additional evidence on the presence and endemic status of Lethal Yellowing in Southeast Asia.

-New Hebrides ${ }^{5}$

During the past 17 years the Saraoutou Coconut Palm Research Station has conducted genetic improvement prograrnmes akning, among other diings, at the production of hybrids of the local "New Hebrides Tall" ("Vanuatu Tall") with foreign material. This includes tall varieties from Rennell islands, the Solomons, Tahiti, West Africa and Malaysia. It was soon discovered that most of the nonindigenous varieties and hybrids (up to 90\%) were, attacked by a wilt disease appearing at the beginning of bearing. Death occurred in a matter of months. The sympornatology of the disease resembles somewhat that of $\mathrm{LY}^{6}$. Under these conditions, the local "New Hebrides Tall" is completely resistant and A seems to transmit its resistance to "New Hebrides Tall x Rehnell Tall" hybrids $(3,7)$. Data on susceptibility of imported material as compared to that of the local "New Hebri'des Tall" is shown in Table IV.

Table IV: Death of imported and native coconut palms at Saraoutou, New Hebrides from 1965-1972 ${ }^{7}$

\begin{tabular}{|l|c|c|}
\hline \multicolumn{1}{|c|}{ Variety } & Palms Planted No. & Palms Dead \% \\
\hline Red Dwarf (Africa) & 217 & 88 \\
Green Dwarf (Fiji) & 182 & 29 \\
Niu Leka & 95 & 81 \\
Rennell Tall & 286 & 61 \\
New Hebrides Tall & 409 & 0 \\
\hline
\end{tabular}

It should be noted that two apparent contrasting reports exist on the response of diseased coconut palms to oxytetracyclmie treatments. Grylls (7), from information obtained at the Saraoutou Station, reported that in 197552 diseased palms were treated with a low dosage of oxytetracyclmie (a total of 5 grams per tree) and that 9 palms showed rermission of symptoms. Dollet and de Taffin (6) in experiments conducted on the sarne station from October 1977 to December 1978 were unable instead to observe any remission of symptoms in 7 palms treated with oxytetracyclmie. They concluded that the treatment was "totally ineffective" and therefore that the disease was not the swne as Lethal Yellowing. However, if comparison is made between these injection tests and those conducted in Jamaica by Hunt et al (13) it can be seen that as many as seven treatments were required in Jamaica over a period of 5 months (with intervals of approximately 10, 40, 60, 100, 125 and 160 days) and a total of $20 \mathrm{~g}$ of tetraqline-HC 1 to obtain symptom remission in only 5 of the 12 treated trees. The strongest response was obtained in palms which had the least leaf yellowing. In

\footnotetext{
${ }^{5}$ Vanuatu.

${ }^{6}$ Since this paper was first presented the disease in Vanuatu has been identified as being caused by the Foliar Decay Virus (Randles, J.W. \& Hanold, D. 1989). Coconut foliar decay virus particles are 20 nanometer isodecahedra. Intervirology 30, 177-180.

${ }^{7}$ Source: Manclot, M. La maladie des cocotiers introduits aux Nouvelles-Hebrides. In Grylls' report (7)
} 
comparison, at Saraoutou only four treatments were made over a period of 10 months (with average intervals of 93.5, 200 and 300 days), the amount of tetracyline actually injected not being reported by Dollet and de Taffm. On the basis of these results further injection expenments would be required before discounting the effect of oxytetracycline and the mycoplasma nature of the disease in the New Hebrides.

Finally, it should be recalled that in Jamaica the New Hebrides Tall shows one of the highest susceptibilities to LY(2). This could be interprested to mean that different strains of the lethal organisms could be developed in different isolated areas of the world.

\section{Other evidencefor an endemic situation in Southeast Asia and the Pacific}

As previously indicated in this paper, one of the characteristics of an endemic disease is its "protean" nature: this is its sudden flaring up in one area followed by a period of relative recession. These conditions appear to exist in Southeast Asia and the Pacific where different wilt disorders, often attributed to various causes and identified under different names, have been reported at different times. These will be bniefly reviewed here.

\section{- $\quad$ Sarawak Wilt}

Sharples $(22,23)$ in 1928 and again in 1933 described a wilt condition in Malaysia affecting areas containing up to 200-300 trees and indicated that these large affected areas, in which up to $50 \%$ of the affected trees died, "occur only at rare intervals". He observed three such areas in 1923, 1926 and 1928. The first evidence of wilt was obtained in the Bernam river district (22). In 1957 a similar condition was observed only on tall pahns by members of the Department of Agriculture in the Semetan Division of Sarawak. It was then reported by Johnson (14) and described by Turner (25, 26) who also had observed a similar condition in areca palm (Areca catechu L.). The symptoms of the wilt disease have been described by both authors as well as by Marmnosch (17), who added the description of necrosis of inflorescences (a symptom which had not been recorded by previous workers). According to recent FAO enquiries in Sarawak, the disease is now rarely seen in that country. The possibility that seed introduced in the Semetan Division has come from Ceylon is suggested by Harries (10). This might account for the susceptibility to wilt expenienced only in this area.

\section{Marinduque Wilt}

This wilt was reported for the first time mi 1963 in Marinduque, which is an island near Luzon (1). The symptomatology resembles that of Lethal Yellowing and Malaysian wilt. No further information on this outbreak is currently available. According to Meadows (18) the malady was due to planting of coconuts on mmie taifings. histead, according to Bigomia (4) occurrence of this wilt in the Philippines has been observed on various occasions and different locations.

\section{Natuna Wilt}

The Natuna group of islands of Indonesia are located north of Sarawak and east of the Malaysian peninsula. A wilt disease was first observed on these islands in 1966. In 1976 an official report stated that about 12,000 palms were dead. A team of Indonesian scientists visited the islands again in April 1978 and estimated that losses had increased to 20,000 palms. The symptomatology is typical of Malaysian wilt (16). The disease appears to be also in the active stage at Bitan (an island south of Singapore) and possibly in Sumatra. No explanation can be given for the fact that the disease is no longer active in Sarawak but it is flaring up northward and westward in fairly isolated places. 
This disorder, recently described by Tumer et al (27), has already mentioned under the topic "Susceptibility of exotics in Indonesia and Malaysia". Its endemic status in this part of the world is also claimed by these authors, mainly on the basis of an apparent susceptibility of the "Malayan Dwarf". It should be noted that while MLOs were reported in three out of four samples of "Malayan Dwarf " seedlings (yellow type) from Peninsular Malaysia, no evidence is produced that the death or difficulty of establishment of "Malayan Dwarf " in Sumatra or elsewhere is due to MLO. However, Turner et al observed that wilt disease of hybrid and dwarf seedhngs occurred in the Bernam River district where 50 years before the wilt disease had been described by Sharples (22).

\section{Considerations and conclusions}

Based on the information available, the following considerations and conclusions were made:

a) Lethal Yellowing in Jarnaica and other systemic lethal diseases in Southeast Asia and the Pacific appear to be co-identical, the difference being mainly an epidemiological one: Lethal Yellowing is truly epidemic in areas where highly susceptible varieties are prevalent, while other similar lethal diseases are endemic in areas where resistant to moderately resistant population exist. Slight differences in symptom expression are closely correlated to certain morphological and physiological characteristics of two well defmed "groups" of coconuts of different origin.

b) The causal agent of Lethal Yellowing is likely to have originated in Southeast Asia (Malaysia/Indonesia) where the disease appears to be endemic and where different levels of "horizontal" resistance (28) have accumulated over time, reaching variable levels of fitness of the host. This varies from the intermediate resistance of "Malayan Tall" to the high degree of resistance of the "Malayan Dwarf " and Indonesian "Nias Dwarf “.

c) The causal agent of different lethal diseases is likely to have evolved in different places to give rise to different "strains" which may vary mi virulence or aggressiveness. We could think of at least four of such strains: one m Malaysia/Indonesia, one in West Africa, one in the Caribbean and one in the Pacific (New Hebrides).

d) Accumulation of resistance genes is likely to occur with a high degree of frequency in a cross pollinated crop such as coconut when this is subjected to disease pressure over sufficient time. An example of this is the resistance of the Malaysian group of coconut in Southeast Asia as demonstrated under Jamaican conditions.

e) If the above considerations are true, it would follow that the movement from one area, to another of germplasm (in the form of seed or pollen of susceptible vaneties or hybrid combinations) creates new epidemiological hazards due to the suspected, existence of site-specific lethal diseases. The use of local germplasm in breeding programmes and the parallel testing of its resistance in certain "strategic" locations should be instead encouraged.

f) New areas of research need to be pursued to confirm or reject the working hypothesis put forward in this paper. FAO could be an excellent forurn for coordinating this undertaking with the full collaboration from the various national and international coconut improvement prograrnmes. This coordinated research appears of great importance and urgency if permanent success is to be attained. 


\section{LITERATURE CITED}

1. Anon (1963) New coco malady infests Marinduque, Coco News, 11, 1-8

2. Anon (1976) Coconut Industry Board, Jamaica, West Indies. Sixteenth Report of the Research Department. $46 \mathrm{pp}$

3. Anon (1977) The Coconut Research Station Saraoutou (New Hebrides). Institut de recherchespour les Huiles et Oleagineux Doc. 1.330

4. Bigomia, A.E. (1979) Personal conununication

5. Carter, W., Latta, R.K. \& Suah, J.R.R. (1965). The symptoms of lethal yellowing disease of coconut palms. FAO Plant Prot. Bull. 13, 49-5 5

6. Dollet, M \& de Taffin, G. (1979) Progress report on the virological study of the New Hebrides coconut disease. 1 Dec. 1978. IRHO Doc. 1437 (a) Paris.

7. Grylls, N. E. (1976) "La maladie" of coconut palms in New Hebrides

8. Harries, H.C. (197 1) Coconut varieties in America, Oleagianeux 26 235-242

9. Harries, H.C. (1973) Selection and breeding of coconuts for resistance to diseases such as lethal yellowing. Oleagianeux 28, 395-398

10. Harries, H. C. (1 97 8) Lethal yellowmg disease of coconuts in global perspective. Phil. J Coconut Studies 3, 1-4

11. Harries, H.C. (1978) The evolution, dissemination and classification of Cocos nucifera. Botanical Review 44, 265-320.

12. Ho, D.T., Loh, H.P.\& Chan, E.(1980) Germination, nursery practices and field planting techniques for MAWA hybrid coconut. Proc. Int. Conf Cocoa \& Coconuts. Kuala Lumpur, Incorporated Society of Planters (1978) pp. 557-567

13. Hunt, P., Dabek, AJ. \& Schuilmig, M. (1974). Rermission of symptoms following tetracyline treatment of lethal yellowing infected coconut pahns. Phytopathology 64, 607-312

14. Johnston, A. (1960). A preliminary plant disease surveymi Sarawak. FAO, Rome.

15. Leppik, E.E. (1970) Gene centres of plants as sources of disease resistance. Ann. Rev.

Phytopath. 8, 323-344.

16. Liyanage, D.V. (1978) Personal communication

17. Maramorosch, K. (1964) A survey of coconut diseases of unknown etiology. FAO, Rome.

18. Meadows, D.J. (1978) Personal communication

19. Purseglove, J.W. (1968) Origin and distribution of the coconut. Trop. Sci. 10. 191-199

20. Renard, J.L. Quillec, D. \& Arnaud, F. (1975) Une nouvelle maladle du cocotier en pepiniere. Oleagineux 30, 169-112 
21. Romney, D.H. (1979) Personal communication

22. Sharples, A. (1928) Pahn Diseases in Malaya. Malayan Ag. J 16, 313- XD

23. Sharples, A. (1933) Lightning storms and their significance in relation t o Cocos nucifera and Hevea brasiliensis. Ann. Appl Biol. 20 1-22

24. Tey, C.C. \& Chan, E. (1980) Diseases of coconut palms in Peninsular Malaysia. Proc. Int Conf On Cocoa \& Coconut, 1978. Pp. 692-707. Incorporated Society of Planters, Kuala Lumpur.

25. Turner, G.J. (1961) A wilt of the coconut palm in Sarawak. Ist interim report (typescript)

26. Turner, G.J. (1963) Observations on previously reported wilt of coconut palm in Sarawak. Trop. Ag. Trin. 40, 115-120

27. Turner, P.D., Jones, P. \& Kenten, R.M.(1978). Coconut stern necrosis: a disease of hybrid and Malayan Dwarf coconuts in North Surnatra and Peninsular Malaysia Perak Planters' Association Journal 1978, pp. 3346

28. Van der Plank, J.E. (1963). Plant Diseases: epidemics and control. Academic press, New York \& London, 349 pp.

29. Van der Plank, J.E. (1 975) Principles of Plant Infection. New York, Academic press 216 pp.

30. Whitehead, RA (1965) Speed of germination, a characteristic of possible taxonomic significance in Cocos nucifera L. Trop. Agric. Trin 42, 369372

31. Whitehead, R.A. (1966) Sample survey and collection of coconut germplasm in the Pacific Islands (30 May - 5 September 1964). Ministry of Overseas Development. HMSO, London

32. Whitehead, R.A. (1968) Collection of coconut germplasm from the Indian/Malaysian Region, Peru and the Seychelles Islands and testing for resistance to Lethal Yellowing disease. FAO, PL: CP/I. 40 pp.

33. Wright, S. (1968 \& 1969) Evolution and the Genetics of Populations: a treatise. U. Chicago Press, 2 vols. 469 pp \& 511 pp. 